\title{
Progress and Suggestion on Compiling GHG Inventories in Cities and Counties Level of China
}

\author{
Du Wang Bing ${ }^{1,2}$, Ma Ning ${ }^{1,2}$, Wang Xiu Yun ${ }^{3}$ \\ ${ }^{1}$ Gansu Science and Technology Development Promotion Center, Lan Zhou, China \\ ${ }^{2}$ Lanzhou Jinshi Resource Environment Technology Limited Company, Lan Zhou, China \\ ${ }^{3}$ Wushan County Dai Jia Gou Primary School, Tian Shui, China
}

Email address:

935254213@qq.com (Du Wang Bing),774534106@qq.com (Ma Ning), 1483469930@qq.com (Wang Xiu Yun)

\section{To cite this article:}

Du Wang Bing, Ma Ning, Wang Xiu Yun. Progress and Suggestion on Compiling GHG Inventories in Cities and Counties Level of China. International Journal of Environmental Monitoring and Analysis. Vol. 5, No. 5, 2017, pp. 134-136. doi: 10.11648/j.ijema.20170505.13

Received: August 20,2017; Accepted: September 28, 2017; Published: October 27, 2017

\begin{abstract}
On December 12, 2015, the Paris agreement, known as "a historic step for human response to climate change" was adopted, and more and more governments and the public were paying attention to climate change. GHG (greenhouse gas) inventory is one of the most basic tasks in tackling climate change. GHG inventory refers to the government as a unit to calculate its greenhouse gas emissions directly or indirectly in the social and production activities. According to the compilation of inventory, the region is divided into national greenhouse gas inventory, provincial greenhouse gas inventory, city and county level greenhouse gas inventory. In this paper, through theoretical analysis about the preparation of GHG compilation of inventory of the national, provincial, city and county level, and combining the existing problems and solutions in the process of GHG compilation of inventory in Jinchang, the author puts forward some suggestions and opinions on GHG emissions inventory of city and county level.
\end{abstract}

Keywords: GHG (Greenhouse Gas), The Compilation of GHG Inventory, City and County Level

\section{Introduction}

On December 12, 2015, the Paris agreement, known as "a historic step for human response to climate change" was adopted, and more and more governments and the public were paying attention to climate change. [1] GHG (greenhouse gas) inventory is one of the most basic tasks in tackling climate change. GHG inventory refers to the government as a unit to calculate its greenhouse gas emissions directly or indirectly in the social and production activities. [2]

\section{Progress in Compiling GHG Inventory in China}

China's national level GHG compilation of inventory originated in the "United Nations Framework Convention on climate change". [3-4] The Convention requires all parties to provide all kinds of GHG emission source and absorption of national inventories sinks, in order to promote the exchange of information about climate change and tackling climate change. Until now China has completed the two national level GHG inventories, and the first time released in 2004 the People's Republic of China Initial National Communication on Climate Change, and the report of GHG inventory was in 1994; The second time released in 2012 the People's Republic of China second national communication on climate change, and its report was in 2005. [5-6] The preparation of the national greenhouse gas inventory report mainly referred to IPCC guidelines for national greenhouse gas inventories (1996 edition), IPCC national greenhouse gas inventory good practice guidance and uncertainty management etc.

Provincial level GHG inventory in China began in September, 2010. The General Office of the National Development and Reform Commission issued notice on the relevant issues concerning the compilation of GHG inventory 
at the provincial level (climate change 2010 No. 2350), which required every region to make work plan and formulate a scheme, and organized the work of GHG inventories. [7] By the end of 2014, the National Development and Reform Commission organized experts to complete the review of the provincial GHG inventories compiled by the provinces of China in 2005 and 2010, marking the completion of the first compilation of the provincial GHG inventory in china. [8] The General Office of National Development and Reform Commission in 2015 issued notice of the General Office of the National Development and Reform Commission on carrying out the work of the compilation of provincial GHG inventories at the next stage (climate change 2015 No. 202). [9] The document required the provinces to compile the inventories of provincial GHG in 2012 and 2014. At present, most provinces have completed the first draft of provincial GHG inventories in 2012 and 2014, pending the next review of national organization. [10] The compilation of the provincial GHG inventory report mainly refers to Guidelines for greenhouse gas inventories at the provincial level issued by the National Development and Reform Commission climate division in 2011 (Trial Implementation). [11]

The country has no mandatory requirements about the GHG inventories of the city and county level at present. [12] The areas to carry out GHG inventories of the city and county level mainly includes the first and second batch of low-carbon pilot cities and Zhejiang province promulgated by National Development and Reform Commission. Until now, Zhejiang province did very well in that. Zhejiang province in 2014 issued the Zhejiang implementation plan for control greenhouse gas emissions (Zhejiang, Office, 2013 No. 144) and the notice of Zhejiang province Development and Reform Commission on carrying out the compilation of GHG inventories (Zhejiang development and Reform Commission Environmental Resources, 2014 No. 103). In the same year, Zhejiang province completed the 2010-2013 annual greenhouse gas inventory report of 11 municipalities and the 9 pilot counties such as Tonglu, Haining, Qing Yuan, and implemented the funds of GHG compilation of inventory about 13 million yuan (including 9 million yuan at the city level, 4 million yuan at the county level). In 2015, Zhejiang Province issued notice on the preparation of greenhouse gas inventories in cities and counties in 2015 (Zhejiang development and Reform Commission Environmental Resources, 2015 No. 245), and launched the work of GHG inventories compilation at city and county level in Zhejiang Province. The compilation of GHG inventories in counties and cities in Zhejiang has positive significance for the development of greenhouse gas inventories in the all cities and counties. In recent years, as per unit of GDP carbon emissions becomes binding assessment indicators of the government, more and more cities start the compilation of GHG inventory, including Lanzhou, Zhangye, Ningbo, Quzhou and Anyang. [13]

\section{Suggestion on Compiling Greenhouse Gas Inventory at County and City Level}

As the country has not yet published the way of the compilation of greenhouse gas inventory at city and county level, there are many difficulties in this aspect. According to the difficulties and solutions in the compilation process of greenhouse gas inventory in Jinchang, the following suggestions are put forward for the compilation of GHG emission inventories in municipalities.

First, it should strengthen the connection with relevant departments. Because the data of greenhouse gas inventory involves a wide range of areas and departments, it is necessary to do well in connection with related departments. The related departments of the compilation of GHG inventory generally includes National Development and Reform Commission, Statistics Department, Industry and Information Committee, Environmental Protection Agency, Forestry Bureau, Agriculture Bureau, Transportation Bureau, airports, power companies, cement, steel, iron, calcium carbide, lime and other key enterprises and institutions.

Second, it is to choose the appropriate method of the compilation of inventory. The inventory of most cities and counties level generally use the guidelines for greenhouse gas inventory at the provincial level (Trial). Because there are great differences in basic statistics of climate change between China's provincial level and city and county level, it will be difficult to compile the greenhouse gas inventory of city and county level if only with guidelines for greenhouse gas inventory at the provincial level (Trial). For example, in energy activities, the burning activities of fossil fuels can use detailed departmental methods (IPCC method 2) in the guidelines for greenhouse gas inventory at the provincial level (Trial), and provincial inventory data can be derived from provincial energy balance sheets. However, most cities and counties don't compile energy balance sheets, therefore in compiling city and county's inventory, on the premise of ensuring the accuracy of the data, it needs to learn from the IPCC guidelines for national greenhouse gas inventories in 2006 and combines with the local data of Satistics Department to determine a reasonable compilation method.

The third is to increase the scope of the report appropriately. The industrial production process only includes 13 production such as cement, steel and calcium carbide in the guidelines for greenhouse gas inventory at the provincial level (Trial). In the process of compiling city and county GHG inventories, there may be little or no production process covering the guide product due to the small area of the city and county level, therefore, it is recommended that, in accordance with IPCC guidelines for national greenhouse gas inventories in 2006, the scope of the industrial process report should be appropriately expanded to more comprehensively calculate GHG emissions from regional industrial production processes. For example, Inventory compilers can combine the main production products of local 
industrial enterprises and properly add iron alloy, ceramics, synthetic ammonia, lead zinc and other products in the process of industrial production. In the accounting of GHG total emissions of production process, there are two kinds of Boundary Calculation: one is in accordance with the guidelines for greenhouse gas inventory at the provincial level (Trial) boundary to calculate emissions load for the comparison between regions; The other is to increase the production process of other products on the basis of the guidelines for greenhouse gas inventory at the provincial level (Trial), to calculate emissions so as to better reflect the local greenhouse gas emissions.

The fourth is to consider indirect emission of new energy power generation. With the country's efforts to develop new energy power generation, the proportion of new energy in the energy structure has improved, so new energy power generation has substantially reduced greenhouse gas emissions. In order to better grasp the contribution of new energy power generation in the greenhouse gas emissions, it is proposed to increase the indirect emission of new energy power generation in calculating the region's total amount of greenhouse gas emissions.

Fifth, government departments will strengthen the capacity building of the compilation of GHG inventories and increase financial investment. The compilation of GHG inventories is a fundamental task in addressing climate change. To improve the greenhouse gas inventory capacity: First of all government departments should strengthen personnel training of the relevant functional departments, improve the statistical summary of the GHG basic data by relevant functional personnel. Next, government departments should strengthen the training of key enterprises and institutions, establish a GHG management system, and do a statistical work on the basic data of greenhouse gas emissions in the production process of enterprises. Finally, government departments should comply with Internet plus, develop the greenhouse gas management system, implement online direct reporting and online review, and make the compilation of greenhouse inventory achieve normalization.

\section{Conclusion}

This paper introduced China's national and provincial, municipal and county level of greenhouse gas inventory preparation, and combining the existing in Jinchang greenhouse gas inventories in the process of making the difficulties and solutions, put forward five suggestions and opinions on greenhouse gas emissions inventory of county-level preparation. Greenhouse gas inventories as a basis for work on climate change, for promoting the concept of low-carbon development in the next step, to respond to climate change led to the adjustment of industrial structure, energy saving and carbon reduction, renewable energy development, ecological protection and construction to provide the basic data and the dynamic monitoring system of work.

\section{Acknowledgements}

This article is one of the phased results for National Development and Reform Commission, China Clean Development Mechanism Fund grant project "Jinchang low carbon pilot project" (number: 2013007), thanks to the fund's support.

\section{References}

[1] Stanley C. T. YIP. Application of Greenhouse Gas Inventory to Urban Rural Planning in China [J]. City Planning, 2013, (2).

[2] ZHU Song-Li, WANG Wen-Tao. Development of National Greenhouse Gas Emissions Inventories in the Context of International Climate Negotiations [J]. Advances in climate change, 2013, (1).

[3] HUANG Wei, GAO Qing-Xian, CAO Guo-liang, M A Zhan-Yun, ZHANG Wei-Ding, CHAO Qing-Chen. Effect of urban symbiosis development in China on GHG emissions reduction [J]. Advances in Climate Change Research, 2016, (4).

[4] Shuang Yang, Wei Yang, Guojun Chen, Xuan Fang, Chengfu Lv, Jiaai Zhong, Lianhua Xue. Greenhouse gas emissions from oilfield-produced water in Shengli Oilfield, Eastern China [J]. Journal of Environmental Sciences, 2016, (8).

[5] Haitao Liu, Jing Li, Xiao Li, Yanhai Zheng, Sufei Feng, Gaoming Jiang. Mitigating greenhouse gas of chemical fertilizer with farmland emissions through replacement organic manure in a temperate [J]. China Science Bulletin, 2015, (6).

[6] Sora Yi, Heewon Yang, Seung Hoon Lee, Kyoung-Jin An. Quantifying and managing regional greenhouse gas emissions: Waste sector of Daejeon, Korea [J]. Journal of Environmental Science, 2014, (6).

[7] Yi Liu, Dongxu Yang. Advancements in theory of GHG observation from space [J]. Chinese science bulletin, 2016, (5).

[8] Daniel Bencsik, Tamas Karches. Estimation of GHG Emissions of a Fixed Bed Biofilm Reactor Cascade in Wastewater Treatment $[\mathrm{J}]$. Environmental Science and Engineering (A), 2015, (11).

[9] Yiqi Mao, Li Chen. Legislation analysis on reducing GHG in Australia [J]. Management scientist, 2014, (7).

[10] Aretha Aprilia Tetsuo Tezuka. GHG Emissions Estimation from Household Solid Waste Management in Jakarta, Indonesia [J]. Energy and power engineering, 2013, (4).

[11] Jin Jiyong. International Institutions and GHG [J]. Modern international relations, 2008, (5).

[12] Yang Shizhi. EEDI Index Assessment and GHG Emission Reduction Measures [J]. China Ship Inspection, 2011, (10).

[13] Takaaki, FURUBAYASHI, Toshihiko, NAKATA. Potentials of GHG reductions from wastewater treatment for the CDM [J]. Chinese Science, 2011, (7). 